\title{
Preference and Consumer Behavior Agrotourism on Campus UPN "Veteran" East Java
}

\author{
Setyo Parsudi ${ }^{1}$, Juli Santoso, Mubarokah, Gyska Indah Harya \\ Department of Agribusiness \\ Universitas Pembangunan Nasional "Veteran" Jawa Timur \\ Surabaya, Indonesia \\ ${ }^{1}$ setyoparsudi@gmail.com
}

\begin{abstract}
Development of agrotourism in unirversities are still rare in Indonesia, including in East Java, especially in Surabaya. National Development University "Veteran" (UPN "Veteran") East Java, especially the Faculty of Agriculture is one of the universities in Surabaya that plans to develop agrotourism in campus/universities that can be used by students and the surrounding communities for a healthy, fun and rewarding recreation and vacation for visitors. In order for the agro-tourism development to go in accordance with customers' expectations, we need a good planning and development-models of agro-tourism, which one should pay attention to the behavior or preference of consumers or potential consumers. Based on that background, thus the importance of this research. This research aims to; 1) Study the consumers' preference in agrotourism 2) Study consumers' behavior in agrotourism, and 3) Create agrotourism development-models that suit the preference and behavior of consumers in campus of UPN "Veteran" East Java and implement the model based on the available resources. The study resulted in the following; For the attractions, most consumers/visitors want to see the collection of plants and animals, harvesting or fruit picking, fishing, as well as processing the products that the visitors' have got. The facilities which consumers want the most are resting spots, WIFI network, toilets, surrounding pathways, and tour guides. Agrotourism consumers' behaviors are as follows; their main goal for visiting is to have a leisure time while gaining more knowledge, the frequency of their visit is mostly once a week, while in the afternoon and evening, many wearing motorcycle transportation together with friends or family. The agrotourism-model that will be developed is one that has agro attractions such as plant collections, crop or fruit picking and fishing as well as agro-processing with the main facilities being the resting spots, there WIFI networks, toilets, surrounding pathways, fishing pond,
\end{abstract} parking lots and tour guides.

Keyword: Agro- tourism development. Preference and consumer behavior

\section{INTRODUCTION}

Tourism has significant values and benefits for the local and global economic context, thus, which is considered as one of the largest industries in the world as it grows rapidly and provided people with various jobs. The agrotourism development according to capabilities, typologies and ecological functions of land will directly influence the sustainability of land resources and the income of farmers and surrounding residents. This activity will indirectly increase the positive perception of farmers and the rest of the people on the importance of preservation of agricultural land resources. Development of agrotourism will, in turn, create jobs since it can absorb labor from rural communities so as to hold or reduce increasing urbanization rate [1]. If understanding the consumer needs and buying process is the foundation for marketing success, then by understanding how buyers behave in the purchase process, will enable marketers to gain an important clue: how to meet the needs of the buyer. By understanding the various behaviors in the process of buying and the things that most affect their buying behavior, marketers can design an effective program for their targeted market [2].

Development of agrotourism in campus grounds is rarely done in Indonesia, including East Java, especially Surabaya. Universitas Pembangunan Nasional (UPN) "Veteran" East Java in particular the Faculty of Agriculture is one of the universities in Surabaya that is concerned about the establishment and development of the Green Campus. Based on that, UPN is planning to develop agrotourism in a campus environment that can be used by students and the nearby residents for their healthy, leisure and educational recreation purposed. In order for the agrotourism to be developed effectively and efficiently, it needs a good plan of agrotourism development of which one must pay attention to the behavior and preferences of cons umers or potential consumers.

The objectives of this research were to: 1) study characteristics of consumers in UPN campus in Surabaya demographically, geographically and economically; 2) assess consumers' preference in UPN campus in Surabaya regarding facilities, attractions, services and the amount of money they are willing to spend when visiting an agrotourism site; 3 ) investigate behavior of potential visitors who will visit the object of agrotourism; and 4) formulate the development model in accordance with the preference and behavior of consumers / visitors of UPN's agrotourism and implement the model based on available resources and the desire of existing stakeholders. 
There are many definitions of agrotourism or farm tourism. The definition of agrotourism utilized in this paper was "visit to farms, ranches, and other agricultural settings with recreational purposes". In this context, examples of agrotourism may include farm stays, pick your own produce, Chrismast tree sales, hayrides, children's educational programs, petting zoos, and on farm fishing and hunting [3]. Agrotourism is an alternative enterprise where you invite the public onto your farm or ranch. It can also be defined as "a set of activities that occur when people link travel with the products, services, and experiences of agricultural" [4]. Agrotourism as a part of selective form of tourism and one of the possible form of diversification of family farms, and as such a desirable model of rural development, is becoming increasingly popular in the world. People more and more choose agrotourism as a place for their holiday [5].

Agri-tourism is a business venture located on a working farm, ranch, or agricultural enterprise that provides an "experience" for visitor while generating supplemental income for the owner. Experiences provided to visitor usually take the form of educational or entertainment discovery and learning in nature or agricultural based environment. For this reason, Agri-tourism is also referred to as "agri-entertainment" and "agro-tourism". Forms of Agri-tourism: Horseback riding, wildlife viewing \& photography, fee fishing, camping/picnicking, fee hunting, wagon rides, school tours, garden/nursery tours, winery tours, agricultural exhibits, game preserve, skeet shooting, exotic farm animals, on farm sales, roadside stand, agriculture related crafts, u-pick operations, festivals/fairs, petting zoo, hunting/working dog trials/training, farm/ranch vacations, B \& B's [6].

Rural tourism and agrotourism are presented as a complex economic activities that highlights, through own mechanism, natural values, cultural and spiritual needs of the rural area. Currently tourism demand becomes increasingly obvious for rest and recreation in the rural area, enjoying the beauties of nature, in clean and quiet environment [7].

Agrotourism benefits for visitors, according to Rilla (1999), are that the visitors can: 1) Establish good relationship with local farmers and residents; 2) Improve health and body fitness; 3) Have some rest and eliminate stress; 4) Get an awesome adventure; 5) Enjoy natural foods; 6) Experience a different atmosphere; and 7) Get a relatively low cost vacation compared to other tourism. Agro-tourism can provide many benefits ti the agricultural producer. It can provide: Cash flow during the off season, opportunity to sell the "experience" of your agricultural venue, opportunity to sell products grown and harvested in your agricultural operation, and opportunity to share your passion of agriculture with others [7].

Factors associated with the success of an agrotourism as a tourist attraction, are: 1) Scarcity; 2) Naturalness; 3) Uniqueness; 4) Involvement of labors; 5) Optimal use of land; 6) Fairness and equality considerations; and 7) Site management.

According to [8], to develop an area into a tourism site (including agrotourism) there are five elements that must be met as follows: Consumer behavior is all decisional acts performed individually or at group level, closely related to the collection and use of goods and services in order to meet current and future needs, containing decision processes that precede and influence these acts. Consumer behavior is represented by the determination of what is purchased, when purchase and why purchase a agro-tourist farm product/service. It combines elements of psychology, sociology, social psychology, anthropology and economics, trying to understand the decision-making process by the purchaser, both individually and in groups [9].

Agrotourism in Spain provides a complex model for the development of agrotourism at Europen Union level. The tourist policies of the Spanish Government, as well as those of the Autonomous Communities, have made significant contributions to the development of agrotourism in Spain and all these may be taken over by the Romanian Government and local public authorities in order to develop a sustainable agrotourism in our country [10].

Rural Tourism in Maramures has prospects of development, imposing, however, the involvement of public authorities and those from the private sector and consumers of tourism products in the conservation of natural and cultural heritage of Maramures villages, without encouraging modernism that can bring significant changes in preserving the.

Attractions in the context of agrotourism development, attractions in question aer, farmland, beautiful scenery, beautiful park, unique traditional farming culture as well as everything related to the agricultural activity.

Facilities required may be the addition of public utilities, telecommunications, hotels and restaurants in the market centers.

Infrastructure is in the form of irrigation systems, communication networks, medical facilities, transportation terminals, sources of electricity and energy, sewage systems, roads and security system.

Public transport, bus station, passenger safety systems, travel information systems, labor, fares certainty, map of the city / attractions.

The hospitality of the residents will be a reflection of a succesful tourism system.

The tourist infrastructure has a traditional rural note, specific to Maramures, aspect that will still be preserved. Development of tourism in Maramures is mainly based on existing diversified potential, but depends mainly on this promotional methods used at local and regional level [7].

\section{RESEARCH METHODS}

Schematically, the framework for designing the model for agro-tourism whihe will be developed in East Java's UPN can be seen below: 


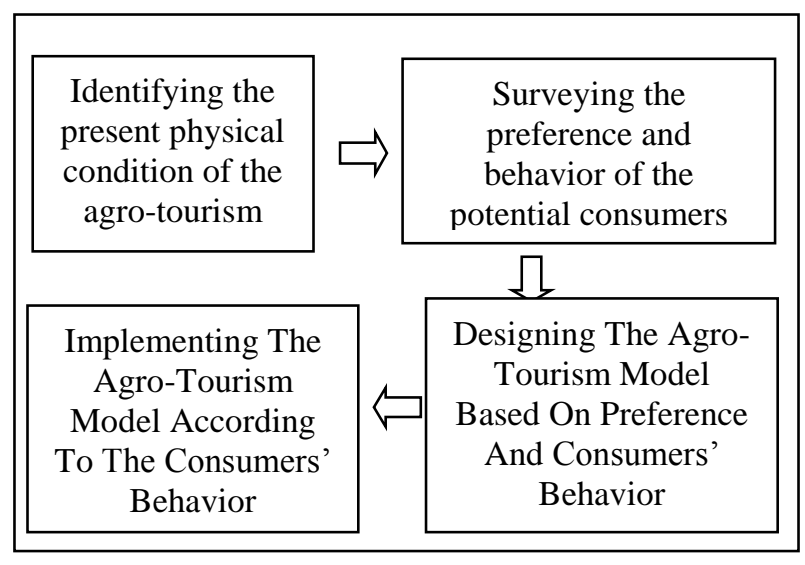

Fig. 1. Research Framework Scheme

Identifying the Present Physical Condition of the AgroTourism area. The first step of this research is to identify the present condition on the field which includes: The types of facility and accommodation available, volumes or sizes, location, up-to-date condition, the cost of maintenance and repair. This identification is done with direct observation on the field by watching, measuring, taking notes, taking pictures, drawing and looking for information regarding the cost of the said maintenance \& repair. The result of this identification will later be presented in the form of a table/chart which will be described later.

Surveying the Preference and Behavior of the Potential Consumers of the Agro-Tourism. This survey is done on UPN campus' ground and the Gunung Anyar and Rungkut district in Surabaya where the Agro-tourism is located and where the consumers reside. The primary data is sampled from respondents by interviews with some questioners and daily records. Secondary data will be taken from the related offices. The examples of the respondents of this research are those who are the potential consumers/visitors of the agro-tourism which is the students \& employees of UPN as well as the residents of Gunung Anyar and Rungkut district. The numbers of the respondents are predetermined as being 100 individuals selected intentionally. The data gathered are then analyzed and then put in some charts which then be described.

Designing the Agro-Tourism Model Based on Preference and Consumers' Behavior. This step is done after the data of consumers' behavior and preference are obtained. Based on those data, we devised plan to develop the agro-tourism as a model that is designed based on the said behavior and preference. The "model" here being the main facilities which are essential, attraction and supporting facilities in the form of map, blue-print and miniature model of the agro-tourism development plan.

Implementing Agro-Tourism Model According to Consumer's Behavior. In this stage, implementation of the agro-tourism model based on consumers' behavior is done. The implementation activities include repairing/fixing the buildings and structures or providing the necessary facilities as well as the appropriate attraction for the consumers/visitors. This implementation is done on the available budget.
Those are the steps of the research for the first year. The next steps will be done in the second year.

\section{RESULTS AND DISCUSSION}

The results of the research involving a hundred respondents who are consumers or potential consumers of the UPN agro-tourism are as follow:

\section{A. Characteristics of the Respondents.}

The result: Most of them are males (62\%), their age are between 20-29 years old (57 \%) mostly single (not yet married) $(66 \%)$, most of them are students $(66 \%)$ most of them are senior high school graduates (64\%) many of them are from Javanese ethnicity (54\%), their income are mostly less than ! million Rupiahs per month $(62 \%)$.

As can be seen from the data, most of the consumers or potential consumers are students and the nearby residents.

\section{B. The Agro-Tourism Preference and Consumers' Behavior.}

- The Agreement of the Agro-Tourism Development. From the the result of the survey hasil survey that has been conducted to 100 people of potential consumers of Agro-tourism, it is found out that a large portion of them $(70 \%)$ agreed and $24 \%$ totally agreed of the development of the UPN's agro-tourism. Only a small number $(6 \%)$ who are against it due to various reasons. Those who agreed, they did so because they like to have place for both recreation and educaation, also as UPN promotion vehicle as well as something that can support conservation of the environment and triggering and improving the students' creativity and additional source of income for the campus. Those who disagreed did so saying the agro-tourism can disturb the learning process of the students and doesn't really well-suited for a campus of national defense like UPN.

- The Willingness to Visit the Agro-Tourism. Regarding the willingness of of the potential consumers to visit the UPN agro-tourism, almost all respondents (92\%) said they are willing to, only a minority $(6 \%)$ who are hesitant due to various reasons. Those who are willing to visit the site said they do so because they can enrich their knowledge, be entertained, and be provided activity during their spare time. Some of them also said that the agro-tourism site is comfortable since it is near their home and some also said that they are curious as well as various other reasons. For those who are hesitant, they feel that there's not nearly enough activities in the tourism-site yet, and some of them said the model for the agro-tourism is still questionable and they are reluctant to pay to enter.

- Time to Visit the Agro-Tourism. About the right or comfortable time to visit the agro-tourism, majority of the respondents $(56 \%)$ want to visit in the afternoon or during the holidays while the other portion of respondents (44\%) wants to visit I the morning during the day when there's no lesson or class activities. This is due to most of the respondents being students or employees of UPN. 
- Transportation Used for the Agro-Tourism. The majority of the respondents $(55 \%)$ opt for motorcycles, some $(14 \%)$ opt for cars while the rest of them (36\%) prefers to walk. This is due to most of the respondents being students or employees of UPN.

- Agro-Tourism Visitors' companions. Regarding who are the potential visitors will ask to go to agro-tourism with them, most of them $(60 \%)$ said they'll go with friends, some $(35 \%)$ will go with their families and the rest of them (22\%) will go alone. This is due to most of the respondents being students or employees of UPN.

- The Purpose of Visiting the Agro-Tourism Site. Regarding the purpose of visiting the agro-tourism, most of them $(69 \%)$ do it for recreational and educational activity. Some (20\%) do it to broaden their horizon or knowledge while the rest of them $(11 \%)$ is for pure leisure or relaxation activity.

- Frequency of Visiting. Regarding the frequency of the consumers' visit, the majority of them (36\%) said once a week while some $(26 \%)$ said once a month and the rest of them either want to visit every day, once a year or just once.

- Activities of the Agro-Tourism Visitors. Regarding the activities that the potential consumers will engage in, many of them (48\%) expect to have some educational observation and sightseeing, some (47\%) want to sightsee and doing some leisure \& relaxation activities and others $(26 \%)$ want to sightsee and buy things, while the rest of them (10\%) just to have a quick sightsee.

- Agro-Tourims Attraction. Regarding the agro-tourism attraction that potential consumers want to see, most of them $(53 \%)$ want to see collections of various plants, cattle, fish and harvesting \& fruit-picking activities. Some $(39 \%)$ want to see the processing of crops. A number of them (39\%) want to go fishing in the fishpond. Others (29\%) want to see the cultivation process and result. The rest of them want to see the more cultural attraction, visiting the park, mini forest, and many others.As for the favorite attraction, 33\% respondents prefer the harvesting and fruit-picking activities, $22 \%$ prefer to fish in the pond and $20 \%$ prefer the crop-processing attraction.

- Facilities of Agro-Tourism. Regarding the facilities in the agro-tourism that the potential consumer want, $63 \%$ of them want some place where they can relax while enjoying the environment which can be in the form of shelter or shed with comfortable chairs. $60 \%$ want WIFI for internet browsing and toilets. 53\% want a path or route for visitors to walk around the site. The rest of them want mushola (praying place for muslims), a place that sells the crops, cafeteria, parking lot, signs, directions or map of the overlaying site, ATM, gamesport facilities, gateway, and many others. As for facilities that deemed essential are toilets (30\%), shed/shelter (25\%), mushola (22\%) and internet (20\%).
The rest of the respondents opt for site-surrounding path for walking, cafeteria, gateway, trading spot, etc.

- Agro-Tourism Hospitality. Regarding the hospitality toward the visitors, many respondents deem it very important $(56 \%)$ and important $(42 \%)$ while the rest of them deem it not important $(2 \%)$ for various reasons. As for the type of hospitality that the respondent want are the basic ones like greetings to te visitors $(70 \%)$ and the availability of guides $(64 \%)$. Other respondents want souvenirs for visitors $(37 \%)$ while the rest of the staff who manage the stand being both males and females or just females.

- Hope Towards Campus' Agro-Tourism. Regarding respondents hope for the existence of UPN's AgroTourism site, most of them $(60 \%)$ want it to be a good recreational spot for the people of the campus and the surrounding neighborhood. Some (55\%) are hoping for the site to be Surabaya city's "lungs". A number of them $(49 \%)$ hope for it to be the a good place for scientific development and conservation for the surrounding environment while. Others hope for the site to be a good place for developing creativity and entrepreneurship of the students $(38 \%)$ and a good place to learn about farming $(37 \%)$.

\section{CONCLUSION}

The result of regarding development model of agrotourism based on consumers' preference and behavior on UPN Veteran campus can be concluded as follow almost all respondents who are potential consumers of UPN Agrotourism site agreed and support the development of agrotourism in UPN campus and willing to visit whenever they are available. As for the ideal time to visit, most ofthem prefer the afternoon while others prefer to visit in the morning or midday and during holidays along with friends or families. Many of them like to use motorcycle to go to the site.

The purpose of the visit is to have educational recreational activity. As for the frequency of the visit, most of the respondents opt for once a week or once a month. The activity that the consumers would like to do is to have educational sightseeing and recreation.

Agrotourism attractions that consumers' want to see are plant and cattle collections, harvesting and fruit-picking, fishing and crop-processing.

The facilities which considered essential by consumers are shelters for resting, WIFI, toilets, mushola and pathway for the visitors surrounding the site. Moreover, consumers want some hospitality displayed by the site's staffs by greeting the visitors and guide them. Many of the consumers prefer the guides to be females. The potential customers' hopes for UPN's agrotourism is for it to become a good recreational place for people in the campus and the surrounding neighborhood. Consumers also hope for it to be the "city lungs" as well as a place for conservation and science development.

The Implementation of the research results is in the forms of blue print and model or mockup of the agrotourism site as 
well as the repair, improvement and construction of essential facilities for the agrotourism such as shelters, pathways, bridges, mushroom houses.

\section{POLICY IMPLICATIONS}

Based on the research results it is suggested that the development of agrotourism in UPN campus need to carry on considering the consumers or potential consumers still have high hopes for the agrotourism plan. Increase in budget is also needed for the repair and construction of the essential facilities. This type of agrotourism also need to be developed in other areas considering the numbers are still few but the potential is great in providing people with a good and healthy recreational place.

\section{ACKNOWLEDGMENTS}

The author would like to thank the Institute of Research and Community Services at the Veteran National Development University of East Java because of the support and opportunities provided so that the writer can produce a scientific work based on the results of research that received funding.

\section{REFERENCE}

[1] E. Rilla, Bring the City \& Country Together. Calofornia Coast and Ocean. Vol.15. No.2.10p, 1999.

[2] P.Kotler, "Marketing Management," 11 edition.Prentice Hall International Inc, New Jersey. 2003.

[3] E. Carpio, Carlos, K. Michael, Wohlgenant, and T. Boonsaeng.. The Demand for Agritourism in the United States, "Journal of Agricultural and Resource Economics," vol. 33(2):254-269. Copyright 2008 Western Agricultural Economics Association, 2008.

[4] Maetzold, A. James, " Nature-Based Tourism \& Agritourism Trends: Unlimited Opportunities," National Alternative Entreprises and Agritourism Leader, USDA/NRCS, Washington, DC, 2013.

[5] Orlie I, K.Brscie,. The Role of Hospitality in Agrotourism. Conference Proceedings.Visit to family farm with additional tourist activity, Tourism \& Hospitality Management, 2012, pp. 355-364 356.

[6] A.H. Dora, "Agri-tourism: A New Agricultural Business Enterprise," Area Agent Community Rural Development, 2008.

[7] C.H. Tabita, T.Iancu, A. Feher, Ramona Ciolac.., "Characterization of Agrotourism Activity in Maramures Area," Research Journal of Agricultural Science, 46 (4), 2014

[8] Spillane, "Prospected and Historical Economi Tourism.," Kanisius, Yogyakarta, 1994.

[9] D. Marin, I. Petroman, M. Popescu, P. Petroman, Iosim Iasmina, Ciolac Ramona, Dumitrescu Carmen, Loziciana, "Factors that Influence Consumer of Rural and Farm Tourism Behavior. LUCRARI STIINTIFICE, Seria I, vol. XV(4), 2014

[10] L. Popescu, R. Catalin CRETU, E. Sima, "Researches Into the Spanish Tourist Policy Aimed at Developing Agrotourism," LUCRARI STIINTIFICE, vol. 54 NR 1/2011. Seria Agronomie. 